\title{
A Study of Students and Teachers' Preferences and Attitudes towards Correction of Classroom Written Errors in Saudi EFL Context
}

\author{
Arafat Hamouda \\ Department of English language and Translation, Faculty of Arabic Language and Social Studies \\ Qassim University, Qassim, Saudi Arabia \\ Tel: 966-503-654-413 E-mail: arafathamouda77@gmail.com
}

Received: February 2, 2011 Accepted: March 15, 2011 doi:10.5539/elt.v4n3p128

\begin{abstract}
It is no doubt that teacher written feedback plays an essential role in teaching writing skill. The present study, by use of questionnaire, investigates Saudi EFL students' and teachers' preferences and attitudes towards written error corrections. The study also aims at identifying the difficulties encountered by teachers and students during the feedback process. The questionnaire findings reveal that both teachers and students have positive attitudes towards written error correction. The study also shows that while teachers and students share such common preferences as the importance of error correction and the types of errors, there are considerable discrepancies as to the techniques of error correction. For instance, students favor the overall correction, whereas most teachers do not. However, the results show that students prefer teacher correction to peer and self-correction. Moreover, both the teachers and students have encountered a number of difficulties, so suggestions have been investigated so as to deal with the problems.
\end{abstract}

Keywords: Preferences, Attitudes, Teacher correction, Error correction

\section{Introduction}

Learning a foreign language is a gradual process, during which mistakes are to be expected in all stages of learning. It is important for both teachers and students to accept the fact that errors are an inevitable part of the learning process (Davies \& Pearse, 2002). It is through students' errors that we can see what they are struggling to master, what concepts they have misunderstood and what extra work they might need (Lavery, 2001). Therefore, errors are often a sign of learning in language acquisition process.

As second-language errors began to be perceived as a necessary and natural process of language learning, learner' errors and feedback to errors have been of great interest to language teachers and researchers (Diab, 2005, Wang, 2010; Katayama; 2007). Most of the studies give more attention to the importance of feedback, ways of providing and receiving feedback as well as what the effect of feedback on students' writing (Lee, 2005; Noora, 2006). What have been neglected in such studies is the preferences and attitudes of the learners and teachers towards error correction (Katayama, 2007).

Understanding these preferences is of paramount importance in the teaching and learning process. This is because, according to Katayama (2007), "differences in learners' learning styles affect the learning environment by either supporting or inhibiting their intentional cognition and active engagement". This stems from the fact that learners are expected to be highly motivated in doing things that they prefer. As such, it is necessary to understand that learners have different preferences i.e. styles in the way they like to be corrected. For instance, some students favor a focus on form, while others do not. Teaching methods also vary. Some instructors tend to correct all the errors while some tend to be tolerant and still some others do not correct at all (Riazi and Riasti, 2007; Noora, 2006). According to the relevant literature on teachers' and students' preferences and attitudes towards error correction, many studies show that while teachers and students share such common views as the importance of error correction and the types of errors that need correcting, there exist considerable discrepancies as to the techniques of error correction (Lee, 2005; Wang, 2010). For instance, students favor the overall correction, whereas teachers do not. In his research, Noora (2006) found that FL students favored a focus on form, but some discrepancies appeared in teachers' beliefs. In a comparison of students' and teachers' beliefs, Diab (2005) also found various discrepancies between EFL instructors' and students' preferences for error correction and paper-marking techniques. Such differences between students' and teachers' expectations and views about feedback can result in unsatisfactory learning outcomes (Riazi and Riasti, 2007; Katayama; 2007). Accordingly, teachers can benefit from discovering their students' preferences in instructional practices. Wang (2010) proposed that "teachers should find out what their students think and feel about what and how they want to learn" (p.140). Leki (1991) also points out that an awareness 
of students' learning styles will enable teachers to adapt appropriate techniques and methods that suit the students' preferences. In addition, matching the learning styles of students in a class and the teaching style of the instructor would help improve students' learning, attitudes, behavior, and motivation (Ferris, 2003)). It is, therefore, crucial to find out the ways through which students prefer to be corrected, hoping that such information can help teachers, in general, and Saudi EFL teachers, in particular, to be more effective in their career.

In conclusion, this study will first focus on both teachers' and students' preferences attitudes towards error correction since these attitudes have a great impact on the entire learning process, and then investigate the difficulties of the teachers in providing feedback and of the students in revising the papers after receiving teacher written feedback.

\section{Research questions?}

1) What are the students and teachers' preferences regarding written error corrections in EFL class?

2) What are the difficulties of the teachers in providing feedback and of the students in revising the papers after receiving their teacher's written feedback?

\section{Definitions}

1) Teacher correction: The teacher corrects all the surface (mainly grammatical) errors by crossing out perceived errors and providing correct answers.

2) "Error correction" is used to refer to the general activity of providing "error feedback" on student errors (Lee, 2005).

\section{Participants}

\subsection{Details of students}

The population for the study consisted of students at Qassim University and the participants in the study were 200 native Arabic speakers. The subjects were two classes of students in the Preparatory Year Program, at Qassim University. Writing was one of the main courses taught to the students of the Preparatory Year Program. The course being taught was Effective Academic Writing (ENG: 141).The students ranged between 18-20 years of age and they were all undergraduates.

\subsection{The teachers}

Along with the students, the present study involved a number of EFL instructors who were invited to participate in the research. This group of participants included 20 instructors who taught English at the Preparatory Year Program of the same university. Their age was between 30 and 45 years old and their experience in teaching English at university level ranged between 3 to 10 years. None of the instructors is native speaker. They were of different nationalities (i.e.saudi, Egyptian, Jordanian, Syrian and Tunisian). All of these instructors were teaching the students who participated in this study.

\section{Data collection}

A questionnaire was devised to see how the students and teachers feel and react to error written correction. The questionnaire items extracted from instruments used in previous studies (Ferris, 2003; Hyland, 2003; Lee, 2005; Radecki and Swales, 1988). The investigator necessarily modified and added items to make the questionnaire relevant and appropriate for the participants. The final version of the questionnaire had two major parts. The first part consists of 51-items. It deals with students and teachers preferences for written error correction. In the second part, two open- questions were designed to find out the difficulties of the teachers in providing feedback and of the students in revising the papers after receiving their teacher's written feedback.

The questionnaire has two versions: the first one was designed for the students, while the second one was for the teachers. Apart from addressing and reference conventions, the two versions do not differ significantly. A questionnaire was given to 22 instructors during the second half of the 2009-2008 spring Semester, and 20 instructors returned completed questionnaires. A matching student version of the questionnaire was administered at the same time to 200 students enrolled in English Writing language classes at the Preparatory Year Program, Qassim University. The results of the student survey appear in (2009) and are compared to the instructors' responses discussed in this paper.

The question in the questionnaire were quantified by a Likert-scale of 1 to 2 ( 1 = Disagree, 2 = agree). The reliability of the first part was determined using Cronbach's alpha (.90).

\section{Results and discussion}

\section{Data analysis}

The frequency for each item of the student and instructor questionnaire was counted and presented in percentages. The choices for each likert scale statement in the questionnaires were combined and presented in eight columns in 
order to get a clearer view of students and instructors' views towards correction of classroom written errors (agree-disagree).

\section{Research results}

In response to the research question on students' and instructors' preferences towards written feedback, the results of their views are presented in this section.

\subsection{Students and teachers' preferences on when to receive feedback}

Table (1) demonstrates the preferred time to provide feedback to students' writings whether in the prewriting, drafting, revising or evaluating. Not surprisingly, when being asked about the best time to provide feedback, all the teachers like to provide feedback during more than one stage of writing process. The students shared the same view with their teachers. By doing this way, the students can get enormous support from teachers through the process of writing; therefore, their progress can be evaluated through a number of stages rather than the only final products.

When asked about their own preferred stages of commenting, only $20 \%$ of teachers gave feedback at the very early stages of writing as it could discourage students from attempting to rewrite if they received their papers with full of red-inked notes. The majority of the students are in line with their teachers' opinion regarding providing feedback during the prewriting stage. More than two thirds of students do not like to get feedback at the early stage of writing. The majority of students $(70 \%)$ would not like their teachers to interfere at the prewriting stage when they were brainstorming and starting to write their first draft. As a whole, the students could have their own favor on each issue of teacher written feedback which they found most suitable and effective in revising their better papers.

Students do not like to get feedback at the drafting and revising stages. However, it was reasonable since the students could ask their friends for help while drafting and revising their papers, and finally turned to the teachers for the final but most important support. But students' preferences were quite different from that of teachers. The majority of teachers like to provide feedback during the drafting (60\%) and revising (70\%) stages. In fact, providing feedback at drafting or revising process could be better than at the evaluating stage. Since corrections on composition made after the process has finished, they seem not to be helpful in improving students' writing (Stanley, 2003). However, it was inferrable that the aim of giving feedback at the last stage of the process may be for the further improvements in the next assignments.

Moreover, a high percentage of students $(80 \%)$ prefer to get feedback at the evaluating stage. A quite number of teachers (90\%) agree with their students' views. The students, in fact, would like to receive feedback "as frequently as possible" (S3). However, because their main concern is the grade" (Freedman, 1987, cited in Cohen \& Cavalcanti, 1990 , p.156), the majority of the students $(80 \%)$ would like to get feedback at evaluating stage. Another reason for this choice may be the notice to avoid mistakes in the next assignments.

\subsection{Students' preferences on the color of pen used to give feedback}

Using a red pen (see table 2.) has got the highest agreement of both students (with 80\%) and teachers (with 95\%) as compared to that of in using pencil with $20 \%$. Undoubtfully, the red pen "was the symbol of the teachers" in the belief of the Saudi; therefore, it was understandable when the students preferred it to other colors of pen utilized to give feedback on their writing papers. Moreover, with red-inked notes, it may be easier for them to see their problems than the comments by pencil. Teachers use red for correcting errors and this is in agreement with learners' expectations about this matter. Strikingly, it could be predicted that there was no teacher using other colors of pens to provide feedback while there was a little favor of using pencils with $20 \%$ of respondents. However, receiving the feedback in pencil, still favored by other $20 \%$ of the students, indicated that these students did not like to be discouraged from rewriting their drafts after getting papers full of red-inked notes. The comments in pencil, in addition, were much more reader-friendly, "relatively tentative, and open to negotiation" (Kate, 2010).

\subsection{Amount of teacher written correction}

Concerning the amount of providing feedback, all the respondents were asked to define how much feedback have they given onto students' writings including correcting all the errors existing in students' writings, selecting some errors existing in students' writing, or correcting nothing. The details, as can be seen clearly from table (3), indicated that none of the teachers corrected any mistakes existing in the students' writing. The instructors' preference is in line with that given by the students (95\%). Although correcting students' writing mistakes could be time and effort- consuming, the teachers have still tried their best for the sake of the students.

When asked about the strategy of selecting some samples of students' errors, the majority of students (60\%) investigated disagreed with the view that selective error correction should be practiced, whereas 12 teachers (60\%) like to select some typical errors which happen frequently in students' writings to correct. As a reason for the teachers' 
preference to selective correction, Diab (2005) in her study stated that it was impractical for the teachers to correct all errors that learners made because of the large size of the classes in which the respondents were enrolled.

As for the comprehensive error correction feedback, a large number of students (70\%) likes their teachers to correct all errors in their writings. This confirms Leki's (1991), Oladejo' (1993) and Halimi' (2008) findings which show that students want all errors in their papers to be corrected. They prefer such correction to be comprehensive, rather than selective.

Unlike their students, the majority of teachers $(65 \%)$ are not in favor of correcting all the errors. As a reason why teachers do not prefer to correct all the errors, Katayama (2007) in his study stated that correcting all the errors for students may lead to the bad impact on the students' self- awareness as they only copied what have been corrected by the teacher into the new papers. Again, it was not surprising to see that students' most common request for teacher feedback was for correction of errors. Though it would take the teachers' enormous time and effort to do so, and though the students would become lazy in thinking of the better changes, they still "wanted to have every error marked" (Leki, 1991, p.62). This finding suggests that there is another mismatch between teachers and students' preference for correcting all errors.

In conclusion, teachers are expected to correct all the errors occurring in the students' writings, however, doing this way could be overloaded work for them. It is better to select the typical ones and leave the rest with suggestions for students to correct.

\subsection{Who should correct leaner's errors?}

As can be seen clearly from table (4), both learners (78.5) and teachers (80) of English showed their preference for teacher correction in the classroom. This finding is consistent with the results of Radecki and Swales' (1988) studies which indicated that the majority of students wanted to be corrected by their teacher. They believed it was mainly the teacher's job to locate and correct errors. They also found that students regarded error marking as a major responsibility of teachers.

When asked whether they like to be corrected by their peers or not, a small number of students (35\%) expressed a strong dislike for peer editing. It is important to note that the majority of the subjects feel that none of their errors should be corrected by their peers. This finding goes in accordance with Oladejo (1993) who, in his study on perceptions on self- and peer-correction among students, discover that the minority of learners would not mind having their written work corrected by peers, while a vast majority of learners were against peer-correction. He also added that peer feedback may be resented by student-writers who may fear ridicule from peers. Students also expressed uncomfortable with peer correction.

Unlike their students, a quite reasonable number of teachers $(70 \%)$ highly appreciate the technique of peer correction. This finding is in consistent with Witbeck (1976 p. 325), who observed that peer correction led to "greater concern for achieving accuracy in written expression in individual students and creates better atmosphere for teaching the correctional aspects of composition"

As for self-correction, from the table, more than half of students (61.5\%) share this view with their teachers $(60 \%)$. This finding indicates that teachers are aware of students' preference on self correction. This finding supports the results of Diab (2005) who indicates that students would gladly correct themselves without external intervention. Thus it seems from the data obtained that these students preferred the teacher to correct their papers, rather than leaving this task to their fellow students.

As a conclusion of the matter of correction techniques, I consider that all of them (i.e. self-correction, peer correction and teacher correction) should be used in classrooms, either when correcting oral or written work.

\subsection{Teachers' and students' preferences for forms of paper-marking techniques}

From table No 5 (see appendix), we can see clearly that both teachers and students prefer to use the forms of giving feedback (i.e. questions, statements, imperatives, exclamations, underlining or circling the mistakes to giving correction codes) differently. Among these forms, "underlining or circling the mistakes" was at the highest rank. Both teachers (70\%) and students (75\%) seem to be in agreement regarding the use of the technique of underlining all the mistakes, writing the correct words, and giving comments at the end of the assignment. Thus, there seems to be a match between teachers' and students' preferences for the circling or underlining techniques. Particularly, the teachers tend to underline or circle the mistakes together with giving the correction codes. Explaining for this frequency, these teachers said that it could help to address the problems students made as it was easy to realize, and moreover, help them to develop their abilities of self-correcting. This finding goes in line with the results confirmed by Halimi (2008) who states that nearly half of the students surveyed also prefer the use of the technique of 
underlining the error. They also found that students preferred to be provided with the correct answer in addition to being told what was wrong.

Noticeably, feedback in the form of exclamations or praises was found to be welcomed by the majority of the surveyed students $(65 \%)$ and teachers $(60 \%)$. The preference for the use of this technique showed that the teachers often praised the students' improvements when comparing the two drafts rather than right at the very first ones.

When asked about their reactions towards the use of the form of "statements", a quite reasonable number of students $(55 \%)$ liked to provide feedback in the form of "statements". The reason why the students preferred this technique to the others was due to its advantages in identifying mistakes easily and in avoiding misunderstanding or confusion. On the other hand, a very small number of the teachers (15\%) favor the technique of using "statements". Explaining the little use of "statements", as stated by one of the teachers, was that sometimes it was hard for teachers to express their ideas in a completed sentence since giving feedback to students' writings needed to be short and simple. Another teacher, in addition, wrote in the questionnaire that the space provided in the writing paper was too small for writing long comments.

Questions and imperatives, on the other hand, were disfavored by the students (25\%) and teachers (10\%) as compared to the three above forms. Answering for these problems may be due to their lack of support in helping the students to rewrite their papers, and moreover, they could lead to confusion or misunderstanding.

As shown in table (5) the responses to the techniques of crossing out indicated that teachers and students seem to be in agreement. Very few teachers (30\%) and students (11\%) prefer the technique of crossing out with correction (e.g. The teacher crosses out what is incorrect and writes in the correct word or structure).This finding goes in accordance with the results of Diab (2005) who indicates that none of the EFL instructors prefer "crossing out what is incorrect and writing the correct word or structure" as the best technique to mark errors in a first draft.

Less than half of the students (30\%) prefer "using correction codes (e.i. SP "spelling", NA "noun agreement", VT "verb tense, WC "word choice", SS "sentence structure"). Thus, there seems that the techniques of crossing out and using correction codes are not favored by students who do not generally choose one particular technique from among those listed. This finding is similar to that reached by Cohen and Cavalcanti's (1990) study which showed that students disfavor the use of the correction codes. The students also remarked that they could not understand over three quarters of the codes when correcting errors in their compositions.

In contrast to the students' preference, $60 \%$ of teachers favor the technique of "using correction codes". Explaining for this frequency, these teachers stated that the aim of using correction symbols was to make students think of the mistakes and become aware of these types of mistakes. Therefore, a table of correction symbols was given to the freshmen at the beginning of the course to ensure that the students know what their mistakes were. The results reported here are consistent with the findings of the studies (Halimi, 2008 and Lee 2004) which showed that teachers clearly expressed a preference for marking codes. Teachers' preference for correction codes was based mainly on the belief that codes would enable the students to understand the types of errors they made. Also, the codes could facilitate error identification.

Thus, it seems that both teachers and students have an agreement in their opinions on a lot of error correction techniques. In other words, there is a discrepancy between teachers' and students' preferences for a small number of error correction techniques.

\section{6 Focus of feedback that students and teachers would like}

Regarding the aspect(s) in writing students would prefer their teacher comments to focus on, it was noticeable that that both teachers and students seemed to desire to get all their problems commented on by the instructors. Although learners generally want their errors corrected, they also have preferences in terms of how much emphasis each error type should attract. The majority of the learners believe that errors relating to grammatical errors should receive the highest attention for correction. Grammar was still needed feedback since some kinds of grammar were considered hard to overcome like run-on or fragment.

Spelling and punctuation errors rank next in order of preference for correction, with more than $75 \%$ of the learners indicating that this error type deserved high attention, or some attention. Learners' preference for error correction shows that mechanical errors are followed closely by vocabulary errors, while content comes after it in order of priority. Receiving the least priority for correction are errors of paragraph construction and organization which the majority of the learners would like to be given little or no attention. This finding was surprising because it was anticipated that the students in the English preparatory program would pay more attention to organization and content rather than grammar; however, it was, unexpectedly, found that the EL students paid more attention to feedback on grammar than organization and content. This finding concurs with Halimi (2008) who found that EFL 
college students tended to value teacher's comments and corrections on grammatical, lexical and mechanical features more than those on content and style.

In finding out how teachers perceived teacher feedback in different aspects, it has been noted that feedback on grammar and content were more important than the other features in writing. Errors in spelling and punctuation and paragraph construction rank next in order of preference for correction. Receiving the least priority for correction are errors of vocabulary which the majority of the learners would like to be given little or no attention.

It seems that there is discrepancy between students and teachers regarding the aspect(s) in writing students would prefer teacher comments to focus on. Teachers and learners differ in their views on how much emphasis should be given to each error type. This could be related to the different demands on the learners at different levels of exposure to the language. This finding is similar to that reached by Diab (2005) and Halimi (2008).

\subsection{Which type of teacher comments do you prefer?}

Unlike the case of forms of feedback, there was not great difference in the choice for each option, which meant that students had taken all kinds of feedback into consideration and agreed on their good effect.

The feedback described in table (6) indicated that $34 \%$ of students and $40 \%$ of teachers prefer the general comments given by the teacher. Both students $(\mathbf{8 0} \%)$ and teachers $(70 \%)$ favor giving detailed and specific comments. Regarding the text-specific feedback, it was noticeable that text-specific got higher proportion with $69 \%$ for "students", and $70 \%$ for "teachers", and 30\% for "sometimes" as compared to that of general feedback with lower proportion for both students and teachers. Text-specific was in general more effective than the general feedback in terms of providing clear and concrete suggestions, so all the respondents agreed that the combination of the two was better.

The second outstanding point going beyond the researcher's expectation was that both teachers $(60 \%)$ and students' (77\%) preferred negative feedback to positive one. Obviously, it was natural of the students to prefer the positive feedback which could encourage and motivate them by praise or exclamation. However, these students expected to receive constructive criticism rather than "simple platitudes" (Hyland, 2003) since they found that it could help them to see the problems instead of getting the general good comments.

As for the use of positive feedback, it is noticeable that a quite reasonable of students $(50 \%)$ and teachers $(70 \%)$ favor positive comments. This finding confirmed the results of other studies which have found that students and teachers surveyed appreciated positive feedback which includes praise (for example, Radecki \& Swales, 1988). They added that positive comments could help to motivate students in rewriting better versions.

When asked about direct and indirect feedback, both teachers and students answered positively. Though students like to get a combination of the two types, it was noted that students favored direct feedback (75\%) to indirect feedback (55\%).An explanation for this was that the majority of students seemed to get improvement if they had all their mistakes pointed out and corrected by the teachers. The situation, however, was not positive as the students depended too much on the support from their teachers in revising the papers without individual attempt. This finding goes in accordance with that of Wang (2010) who reported that it was understandable as the direct feedback was much better than the latter since it provided the increase of motivation in students and also contributed to improve students' self-edited ability.

Strikingly from table No. (7), margin feedback and end feedback were highly valued by teachers. Unlike their teacher, a small number of students would like their teacher to use margin feedback and end feedback. An explanation for the teachers' preference for margin feedback and end feedback was that although end comments take a lot of time to summarize what teachers would like their students to focus on. teachers think they still need to do so for the sake of their students. In conclusion, using a combination of different types of feedback could yield more good effect for the students' improvement in rewriting their papers.

\section{8 What do you usually do after you read your teacher's comments and corrections?}

When asked how often they read over their writing again after their teachers returned it to them, both teachers $(60 \%)$ and students $(68 \%)$ agreed that learners like to read every mark/comment their teachers wrote on their pieces of work carefully. This finding is similar to that reached by Halimi (2008) who said that $63 \%$ of students state that they read every correction carefully.

More than two thirds of students (83\%) are mostly concerned and motivated about the grade. $90 \%$ percent of teachers are in line with their students' views. This statistics goes in contrast with the results of Halimi (2008) who indicated that none of the respondents like having their work graded either. 
Teachers and students also agree that learners prefer to ask their teacher and classmates for help. It was easier for students to ask their classmates for help for being comfortable, and not fearful. However, classmates sometimes could not give the satisfying answers; therefore, teachers were the ones to giver further explanation and suggestions. By asking the teachers directly, students' confusion or hard-to-understand problems could be solved. This finding confirmed the results by Chiang Kwun-Man, Ken 2004 who stated students asked their classmates and teacher, checked dictionaries, and checked grammar books to respond to their teacher's feedback.

$66.5 \%$ of students like to go to the library to consult reference materials (e.g. grammar book, dictionary), whereas $60 \%$ of teachers state that learners don't do that. Only $30 \%$ of teachers also think that students like to make correction themselves, a high percentage of students answered positively. However, looking up the words in the dictionary, besides, may be convenient for students as each could possess at least one dictionary; however, for other complex matter as expressions or content, the dictionary could not contribute much help. This finding is in line with the students $(60.7 \%)$ who like to make correction themselves.

Very small number of students ignores the comments because they do not know how to make the corrections, whereas fifty percent of teachers see the opposite..

$27 \%$ of students responded that they did not read over their composition. $73 \%$ of students responded that they like to read the entire composition again after their teacher has marked it. As such, there is a mismatch between the opinions of teachers and that of learners.

As for using the Internet to find more references, both students (70\%) and teacher (60\%) agree that the majority of learners prefer the use of the Internet to find more information. using the internet to find more references indicated that the students here have the skills to utilize such kinds of helpful resources in enhancing their papers. The reasons, in general, may be due to the availability of the facilities and equipment; however, students' attitudes as well as perceptions should also be taken into consideration.

Regarding asking other instructors for help, a considerable number of students and teachers think that the students may have their own ways as asking the other teachers, their English friends, or their "roommates to help". Doing such ways could contribute to deal with the problems, nevertheless, not many students could have the foreign friends or could dare to ask other teachers.

In conclusion, various research studies have in fact indicated (e.g. Ferris, 2003) that students do encounter problems in understanding their teacher comments because the instructions are not clear. Ferris (2003) gave an example illustrating that students may fail to interpret a teacher's question as a suggestion for information, and it is not surprising to find that students ignore it when they do revision. It is, therefore, suggested that teachers should explain their responding behavior to their students (Zamel, 1985).

\subsection{How do you feel about your teacher's comments?}

From table No.9, it is noticeable that students' responses to these items in question No.9 are also in line with their instructors' response regarding the students' feelings towards the given feedback. Question 9 examined whether students felt teacher's feedback was helpful. Teachers and students seem to be in agreement regarding learners' attitudes towards feedback. High percentage of students $(90 \%)$ and teachers $(80 \%)$ expressed that teacher feedback was not negative and discouraging. Students also believe that teacher feedback was not general. The same finding is also supported by the instructors' opinion (See Table 9).

93.5\% of students also declared that they "enjoy the teacher's comments on their composition". This finding is in line with instructors' (50\%) opinion.

The same percentage ( $80 \%$ ) of both students and instructors felt that the teacher's comments and corrections help the learners to know what to avoid/improve next time.

Many students and teachers thought that the teacher's comments and corrections help learners to know where their mistakes are and correct them.

The majority of the students surveyed (75\%) feel that their writing has improved because of the comments given on their paper. The same opinion has been confirmed by their instructors $(80 \%)$.

In response to how learners feel about the feedback given by their instructor, a high percentage of students (77\%) think that the feedback given makes learners feel good about themselves. $80 \%$ of instructors were in line with their students' opinion.

It seems that both students and instructors agreed that learners like the way their composition is marked. This finding is similar to the results of Diab (2005); and Lee' (2005) studies which showed that students were eager to receive teachers' feedback on their writing and they believe that they benefit from it. 
In general, survey research has reported that students value the feedback they receive on their errors in writing (Leki 1991, Radecki \& Swales 1988) and this study lends further support to this notion.

\section{What are the difficulties of teachers in providing feedback and of students in revising the papers after receiving teacher's written feedback?}

It was unavoidable for both teachers and students to encounter the difficulties during the process of giving and receiving feedback. To get deeper understanding of these problems, the obstacles of each group would be analyzed separately based on the data taken from the questionnaires.

\subsection{Difficulties of teachers in providing feedback}

Responding to the open-question " What are the difficulties of teachers in providing feedback?" teachers considered their hindrances in giving feedback to the students' writings as follows:

There was no surprise that taking a lot of time and effort to give comments and having too many papers to mark were the two major difficulties that teachers faced when providing feedback to students' writings. This finding goes in accordance with the results of Leki (1991) who reports that "responding to and commenting on students writing consumes the largest proportion of our time..

Apart from "time and effort consuming" (Leki, 1991), having too many papers to mark could cause numerous problems as the teachers sometimes could not thourously read the papers and as results, could not point out all the mistakes made by the students as well as provided them with more suggestions.

Coming next on the rank was that the students made too many mistakes with $60 \%$ of the respondents (12 out of 20) choosing the option. When learners are making so many mistakes, it may be "futile for the teacher to try to correct every error on the paper, and it will be a waste of both time and effort to the teacher" (Gulcat and Ozagac, 2004).

The fact that "if there is a grade on a paper, students read the grade and simply discard the paper"(Leki, 1991) was another trouble for the teachers which could discourage them from providing feedback to the students' writing. However, it was not the serious problems for the teachers as it only took the concern of $30 \%$ of the teachers.

$10 \%$ of the teachers presented another hindrance which was "the students don't understand the feedback". Giving reason for this, Stannard, 2008 claimed that the space provided was too narrow to write a long and detailed feedback, hence the students found it difficult to grasp.

In summary, it is impossible to point out all the obstacles teachers have encountered when providing feedback to the students' writing. It is also true that teachers sometimes "cannot be aware of the difficulties arisen". However, though numerous problems have been revealed during the process of giving feedback, and though "it takes time and effort to provide such detailed and through comments", teachers have still continued to do that for the sake of students as "our students desire for this feedback".

\subsection{Students' problems when revising papers after getting feedback}

Similar to teachers facing the problems during the process of giving feedback, students, in turn, have encountered enormous difficulties in revising the papers after getting teacher written feedback. The data of this part was drawn from the questionnaires for students.

One of the largest difficulties students encountered in revising the papers after getting teacher written feedback was students' fear of making other new mistakes with $35.5 \%$ of the students. Hyland (2003) accounts for the highest proportion by mentioning that there were large number of reasons for making new mistakes such as these due to students' carelessness, students' habit of making those kinds of mistakes, and even students' struggle for rewriting the papers "without actually understanding what they were correcting"(Stannard, 2008).

Again, the inability in revising the content and the expressions suggested by the teacher and in correcting all the grammatical and mechanic mistakes were the problems students faced when revising the papers with $30 \%$.

Different from the students having problems when revising the paper, $35.5 \%$ of the students were quite confident to state that they did not have any problem in rewriting their papers after getting feedback. This finding was positive since students could take advantages of teacher's help to revise their papers in order to achieve the progress.

The other $9 \%$ of the students added more problems they had faced as sometimes they do not know how to rewrite the papers even after receiving the teacher's written feedback.

Despite the teachers' time and effort consumed to provide feedback on the students' writings, large number of students still claimed that misunderstanding the teacher written feedback was the main reason of their inability to revise their papers, which accounted for highest percentage $(25.5 \%)$ as compared to the others. It was serious that this matter would result in the students' ignorance to feedback when rewriting their papers (Stannard, 2008), or it 
could "lead to feelings of confusion and frustration as well as action and indifference on behalf of the students" (Williams, 2003)

Having too many mistakes to revise (20\% of the students), was another drawback discouraging students from rewriting their papers. This is similar to the findings by Gulcat and Ozagac (2004).

It is true that the teacher's written feedback is not always helpful when it was "unclear and vague" (Cohen and Cavalcanti, 1990), and students sometimes could not agree with these comments and suggestions. Among the students completing the questionnaires, more than $20 \%$ of them look for these two problems to explain why they sometimes could not revise their papers.

Of all the $23 \%$ of the students who had other ideas on the matter, a small proportion wrote that they could revise the papers after getting teacher's written feedback. Another proportion, however, considered the lack of time and the unclear pointed mistakes are the reasons for not being able to revise the drafts.

\section{Conclusion}

The purpose of this study was to explore EFL university instructors' preferences for error correction and paper-marking techniques and their beliefs about what constitutes effective feedback to writing and to compare instructors' preferences and beliefs to those of their students. The analysis of teacher and student responses revealed various discrepancies between instructors' and students' preferences for error correction and paper-marking techniques, as well as differences in beliefs among instructors themselves. Just like the class (seventy to one hundred students) in which the respondents were enrolled, Saudi university EFL classes are usually large. Teachers often have these students engage in communicative activities in pairs and groups. Unavoidably, teachers cannot correct all the errors the students make. Despite the strongly positive attitudes toward teacher correction that the respondents expressed, it was not feasible for teachers to spend much of the instruction time dealing with errors.

Nunan (1987) argued, "One of the most serious blocks to learning is the mismatch between teacher and learner expectations about what should happen in the classroom" (p.177). Many language educators and researchers support this view (e.g., Green \& Oxford, 1995; Katayama, A. (2007). Given that matching students' and teachers' expectations is vital for successful language learning, it can be hoped that teachers will take the time to discover their students' attitudes toward pedagogical practice. When circumstances do not allow teachers to modify their classroom practices, they should explain their rationale to their students. Such explanations could at least partially minimize conflict in expectations between teachers and students (Katayama, 2007).

Although the sample of this study consists of two hundred participants, no generalization can be drawn because the study sample was not a large one. Despite this drawback, it can be argued that the findings of this study provide useful information that may contribute to our understanding of students' perceptions of classroom error correction. Therefore, it is recommended that teachers incorporate classroom discussions on error correction, feedback, and writing in order to help their students understand how feedback is intended to affect their writing and why it is given in a particular way. And just as important, it is recommended that teachers become aware of their own beliefs about error correction and feedback to student writing.

The findings of this study lead to implications for future research. One recommendation is research that addresses the reasons for the students' preferences for particular correction methods as well as their preferences for classroom error corrections of different types of errors. Another recommendation is that another study can be conducted with a large and different sample.

\section{References}

Chiang Kwun-Man, Ken. (2004) an Investigation into Students' Preferences for and

Responses to Teacher Feedback and Its Implications for Writing Teachers. Hong Kong Teachers' Centre Journal Vol. 3 (C) Hong Kong Teachers' Centre 2. edb.org.hk/hktc/download/journal/j3/10.pdf

Cohen, A.D. (1991). Feedback on writing: the use of verbal report. Studies in second language acquisition. Cambridge: Cambridge University Press.

Cohen, A D, \& Cavalcanti M C. (1990). Feedback on compositions: Teacher and student verbal reports. In B Kroll (Ed.), Second Language Writing: Research Insights for the Classroom. Cambridge: Cambridge University Press.

Diab, R. L. (2005). EFL university students' preferences for error correction and teacher feedback on writing. TESL Reporter, 38, 27-51. From https://ojs.lib.byu.edu/spc/index.php/TESL/article/viewFile/3809/3555

Ferris, D. R. (2003). Response to student writing: Implications for second language. 
Green, J. M. \& Oxford, R. (1995). A closer look at learning strategies, L2 proficiency, and gender. TESOL Quarterly, 29, 261-297. doi:10.2307/3587625, http://dx.doi.org/10.2307/3587625

Gulcat, Z., \& Ozagac, O. (2004). Correcting and giving feedback to writing. Retrieved December 12, 2008 from http://www.buowl.boun.edu.tr/teachers.

Halimi, Sisilia S. Indonesian teachers' and students' preferences for error correction. Wacana, VOL. 10 NO. 1, APRIL 2008 (50-71). journal.ui.ac.id/?hal=downloadWacana\& $q=4$

Hyland, F. (2003). Focusing on form: Student engagement with teacher feedback. System, 31, 217-230.

doi:10.1016/S0346-251X(03)00021-6, http://dx.doi.org/10.1016/S0346-251X(03)00021-6

Katayama, A. (2007 ). Japanese EFL Students' Preferences toward Correction of Classroom Oral Errors. Volume 9. Issue 4 Article 19. http://www.asian-efl-journal.com/Dec_2007_ak.php

Kate Westberg, (2010). Should Students do more? A Case for Peer Learning and Immediate Feedback. Anzmace RMIT University, kate.westberg@rmit.edu.au

Lee, I. (2005). Error correction in the L2 writing classroom: What do students think? TESL Canada Journal, 22 (2). http://www.teslcanadajournal.ca/index.php/tesl/article/view/84

Leki, I. (1991). The preferences of ESL students for error correction in college-level writing classes. Foreign Language Annals, 24(3), 203-218. doi:10.1111/j.1944-9720.1991.tb00464.x,

http://dx.doi.org/ doi:10.1111/j.1944-9720.1991.tb00464.x

Noora, A. Iranian Non-English Majors' Language Learning preferences: The Role of Language Institutes. 2006C Developing Teachers.com. http://www.asian-efl-journal.com/site_map.php

Nunan, D. (1987). Communicative language teaching: The learner's view. In K. D. Bikram (Ed.), Communication and learning in the classroom community, (pp. 176-190). Singapore: SEAMEO Regional Language Centre.

Oladejo, J. A. (1993). Error correction in ESL: Learners' preference. TESL Canada Journal, 10(2), 71-89. http://www.teslcanadajournal.ca/index.php/tesl/article/view/619/450

Prior, P. (1991). Contextualizing writing and response in a graduate seminar. Written Communication, 8, 267-310. wcx.sagepub.com/content/8/3/267. doi:10.1177/0741088391008003001,

http://dx.doi.org/ 10.1177/0741088391008003001

Radecki, P., \& Swales, J. (1988). ESL student reaction to written comments on their written work. System, 16, 355-365. deepblue.lib.umich.edu/bitstream/2027.42/27547/1/0000591.pdf

doi:10.1016/0346-251X(88)90078-4, http://dx.doi.org/10.1016/0346-251X(88)90078-4

Riazi, A. \& Riasati, M. "Language Learning Style Preferences: A Students Case Study of Shiraz EFL Institutes." Asian EFJ Journal. 2007. linkinghub.elsevier.com/retrieve/pii/S1877042810020355

Sevgi EREL, S. and BULUT, D. (2007). Error Treatment in L2 Writing: A Comparative Study of Direct And Indirect Coded Feedback in Turkish EFL Context. Sosyal Bilimler Enstitüsü Dergisi Sayl: 22 Yll : 2007/1 (397-415 s.). sbe.erciyes.edu.tr/dergi/sayi_22/24-\%20(397-415.\%20syf.).pdf-Similar

Stannard, J. (2008). A new direction in feedback. Retrieved December 20, 2008 from http:/hltmag.co.uk/dec08/mart04.htm

Tedick, D. (1998). Research on error correction and implications for classroom teaching Longman. From www.carla.umn.edu/immersion/acie/vol1/Bridge1.3.pdf-

Veerman, N. O. (1999). Adult student reaction to teacher response. Unpublished doctoral thesis, University of Central Florida, Orlando, FL.

Wang, P. Dealing with English Majors` Written Errors in Chinese Universities. ISSN 1798-4769 Journal of Language Teaching and Research, Vol. 1, No. 3, pp. 194-205, May 2010 (C) 2010 Academy Publisher Manufactured in Finland. From www.academypublisher.com/ojs/index.php/jltr/article/viewFile/.../1797

Williams, J.G. (2003). Providing feedback on ESL students' assignments. Retrieved December 10, 2008 from http://iteslj.org/Techniques/Williams-Feedback.html

Witbeck, M. C. (1976). Peer correction procedures for intermediate and advanced ESL composition lessons. TESOL Qumterly, 10(3),321-326. doi:10.2307/3585709, http://dx.doi.org/ 10.2307/3585709

Zamel, V. (1985). Responding to student writing. TESOL Quarterly, 19(1), 79-102. 
doi:10.2307/3586773, http://dx.doi.org/ 10.2307/3586773

Table 1. Students and teachers preferences on when to give feedback

\begin{tabular}{|l|l|l|l|l|l|l|l|l|l|}
\hline \multirow{2}{*}{ o1 } & \multirow{2}{*}{ I prefer to get my feedback } & \multicolumn{4}{|l|}{ Students } & \multicolumn{3}{l|}{ Teachers } \\
\cline { 3 - 11 } & & $\mathrm{Y}$ & $\%$ & $\mathrm{~N}$ & $\%$ & $\mathrm{Y}$ & $\%$ & $\mathrm{~N}$ & $\%$ \\
\hline \multirow{3}{*}{} & 1) at the prewriting stage & 60 & 30 & 140 & 70 & 4 & 20 & 16 & 80 \\
\cline { 2 - 12 } & 2) at the drafting stage & 40 & 20 & 160 & 80 & 12 & 60 & 8 & 40 \\
\cline { 2 - 11 } & 3) at the revising stage & 130 & 65 & 70 & 35 & 14 & 70 & 6 & 30 \\
\cline { 2 - 11 } & 4) at the evaluation stage & 160 & 80 & 40 & 20 & 18 & 90 & 2 & 10 \\
\hline
\end{tabular}

Table 2. Color of pen that students would like Teacher to give feedback

\begin{tabular}{|c|c|c|c|c|c|c|c|c|c|}
\hline \multirow{2}{*}{ o1 } & \multirow{2}{*}{$\begin{array}{l}\text { In giving feedback, I like my teacher } \\
\text { to use }\end{array}$} & \multicolumn{4}{|c|}{ Students } & \multicolumn{4}{|c|}{ Teachers } \\
\hline & & $\mathrm{Y}$ & $\%$ & $\mathrm{~N}$ & $\%$ & $\mathrm{Y}$ & $\%$ & $\mathrm{~N}$ & $\%$ \\
\hline & 5) the red pen & 160 & 80 & 40 & 20 & 19 & 95 & 1 & 5 \\
\hline & 6) the pencil & 40 & 20 & 160 & 80 & 2 & 10 & 18 & 90 \\
\hline
\end{tabular}

Table 3. Students and teachers views regarding the amount of teacher written correction

\begin{tabular}{|l|l|l|l|l|l|l|l|l|l|}
\hline \multirow{2}{*}{} & \multirow{2}{*}{ 1.It would be better if my teacher: } & \multicolumn{3}{|l|}{ Students } & \multicolumn{2}{l|}{ Teachers } \\
\cline { 3 - 11 } & Y & $\%$ & $\mathrm{~N}$ & $\%$ & $\mathrm{Y}$ & $\%$ & $\mathrm{~N}$ & $\%$ \\
\hline & 7) corrects all the errors & 140 & 70 & 60 & 30 & 7 & 35 & 13 & 65 \\
\cline { 2 - 11 } & 8) selects some errors & 80 & 40 & 120 & 60 & 12 & 60 & 8 & 40 \\
\cline { 2 - 10 } & 9) doesn't correct any error & 10 & 5 & 190 & 95 & 0 & 0 & 20 & 100 \\
\hline
\end{tabular}

Table 4. Students and teachers views regarding the issue of who will do the correction

\begin{tabular}{|l|l|l|l|l|l|l|l|l|l|}
\hline \multirow{2}{*}{ 3. Class error correction. Who? } & \multicolumn{4}{|l|}{ Students } & \multicolumn{3}{l|}{ Teachers } \\
\cline { 3 - 11 } & & $\mathrm{Y}$ & $\%$ & $\mathrm{~N}$ & $\%$ & $\mathrm{Y}$ & $\%$ & $\mathrm{~N}$ & $\%$ \\
\hline \multirow{3}{*}{} & $10)$ the teacher & 157 & 78.5 & 43 & 21.5 & 16 & 80 & 4 & 20 \\
\cline { 2 - 11 } & 11) your peers & 70 & 35 & 130 & 65 & 14 & 70 & 6 & 30 \\
\cline { 2 - 11 } & $12)$ self-correction & 123 & 61.5 & 77 & 38.5 & 12 & 60 & 8 & 40 \\
\hline
\end{tabular}


Table 5. Students and teachers preferences for forms of paper-marking techniques

\begin{tabular}{|c|c|c|c|c|c|c|c|c|}
\hline \multirow{2}{*}{$\begin{array}{l}\text { 4. How would you like your teacher } \\
\text { to correct your errors in writing? }\end{array}$} & \multicolumn{4}{|c|}{ Students } & \multicolumn{4}{|c|}{ Teachers } \\
\hline & $\bar{Y}$ & $\%$ & $\mathrm{~N}$ & $\%$ & $\mathrm{Y}$ & $\%$ & $\mathrm{~N}$ & $\%$ \\
\hline 13)writing questions & 40 & 20 & 160 & 80 & 2 & 10 & 18 & 90 \\
\hline 14) statement & 110 & 55 & 90 & 45 & 3 & 15 & 17 & 85 \\
\hline $\begin{array}{l}\text { 15)underlining the error and write } \\
\text { comments at the end of the essay }\end{array}$ & 150 & 75 & 50 & 25 & 16 & 80 & 4 & 20 \\
\hline 16) using imperatives & 30 & 15 & 170 & 85 & 4 & 20 & 16 & 80 \\
\hline 17) using exclamations & 130 & 65 & 70 & 35 & 12 & 60 & 8 & 40 \\
\hline $\begin{array}{l}\text { 18) crossing out the error and writing } \\
\text { in the correct word or structure }\end{array}$ & 22 & 11 & 178 & 89 & 6 & 30 & 14 & 70 \\
\hline 19) using correction codes & 32 & 16 & 168 & 84 & 14 & 70 & 6 & 30 \\
\hline
\end{tabular}

Table 6. Focus of feedback that students and teachers would like

\begin{tabular}{|l|l|l|l|l|l|l|l|l|}
\hline \multirow{2}{*}{$\begin{array}{l}\text { 5. Which aspect(s) in writing would you } \\
\text { prefer teacher comments to focus on? }\end{array}$} & \multicolumn{3}{|l|}{ Students } & \multicolumn{2}{l|}{ Teachers } \\
\cline { 2 - 11 } & $\mathrm{Y}$ & $\%$ & $\mathrm{~N}$ & $\%$ & $\mathrm{Y}$ & $\%$ & $\mathrm{~N}$ & $\%$ \\
\hline 20) grammar & 92 & 82.1 & 20 & 17.9 & 20 & 100 & & \\
\hline 21) mechanics (e.g. punctuation, spelling) & 84 & 75 & 28 & 25 & 16 & 80 & 4 & 20 \\
\hline 22) vocabulary choice & 80 & 71,4 & 32 & 28.6 & 14 & 70 & 6 & 30 \\
\hline 23) content & 70 & 62.5 & 42 & 37.5 & 20 & 100 & & \\
\hline 24) organization and paragraph construction & 68 & 60.7 & 44 & 39.3 & 16 & 80 & 4 & 20 \\
\hline
\end{tabular}

Table 7. Students and teachers' preferences for types of feedback

\begin{tabular}{|l|l|l|l|l|l|l|l|l|}
\hline \multirow{2}{*}{$\begin{array}{l}\text { 7. Which type of teacher comments do } \\
\text { you prefer? }\end{array}$} & \multicolumn{4}{|l|}{ Students } & \multicolumn{2}{l|}{ Teachers } \\
\cline { 2 - 11 } & $\mathrm{Y}$ & $\%$ & $\mathrm{~N}$ & $\%$ & $\mathrm{Y}$ & $\%$ & $\mathrm{~N}$ & $\%$ \\
\hline 25) general comments & 68 & 34 & 132 & 66 & 8 & 40 & 12 & 60 \\
\hline 26) detailed and specific comments & 138 & 69 & 62 & 31 & 14 & 70 & 6 & 30 \\
\hline 27) positive comments & 110 & 55 & 90 & 45 & 14 & 70 & 6 & 30 \\
\hline 28) negative comments & 154 & 77 & 46 & 23 & 17 & 85 & 3 & 15 \\
\hline 29) direct feedback & 84 & 75 & 28 & 25 & 12 & 60 & 8 & 40 \\
\hline 30) indirect feedback & 106 & 53 & & & 10 & 50 & 10 & \\
\hline 31) margin feedback & 70 & 35 & 130 & 65 & 16 & 80 & 4 & 20 \\
\hline 32) end feedback & 65 & 32.5 & 135 & 67.5 & 14 & 70 & 6 & 30 \\
\hline
\end{tabular}


Table 8. Students and teachers' views regarding what students usually do after they read their teacher's comments and corrections

\begin{tabular}{|c|c|c|c|c|c|c|c|c|}
\hline \multirow{2}{*}{$\begin{array}{l}8 . \text { What do you usually do after you read } \\
\text { your professor's comments and corrections? }\end{array}$} & \multicolumn{4}{|c|}{ Students } & \multicolumn{4}{|c|}{ Teachers } \\
\hline & $\mathrm{Y}$ & $\%$ & $\mathrm{~N}$ & $\%$ & $\mathrm{Y}$ & $\%$ & $\mathrm{~N}$ & $\%$ \\
\hline $\begin{array}{l}\text { 33) I like to read every mark/comment my } \\
\text { teacher wrote on my piece of work } \\
\text { carefully. }\end{array}$ & 136 & 68 & 64 & 32 & 12 & 60 & 8 & 40 \\
\hline $\begin{array}{l}\text { 34) I am mostly concerned and motivated } \\
\text { about the grade. }\end{array}$ & 166 & 83 & 34 & 17 & 18 & 90 & 2 & 10 \\
\hline 35) I ask my teacher for help. & 180 & 90 & 20 & 10 & 16 & 80 & 4 & 20 \\
\hline 36) I ask some other teachers for help. & 132 & 66 & 68 & 34 & 10 & 50 & 10 & 50 \\
\hline $\begin{array}{l}\text { 37) I use the Internet to find more } \\
\text { references. }\end{array}$ & 140 & 70 & 60 & 30 & 12 & 60 & 8 & 40 \\
\hline $\begin{array}{l}\text { 38) I go to the library to consult reference } \\
\text { materials (e.g. grammar book, dictionary). }\end{array}$ & 133 & 66.5 & 67 & 33.5 & 8 & 40 & 12 & 60 \\
\hline 39) I ask my classmates for help. & 80 & 71.4 & 32 & 28.6 & 12 & 60 & 8 & 40 \\
\hline 40) I make correction myself. & 68 & 60.7 & 22 & 39.3 & 6 & 30 & 14 & 70 \\
\hline $\begin{array}{l}\text { 41) I ignore them because I do not know } \\
\text { how to make the corrections. }\end{array}$ & 20 & 10 & 180 & 90 & 10 & 50 & 10 & 50 \\
\hline $\begin{array}{l}\text { 42) I don't like to read the entire } \\
\text { composition again after my teacher has } \\
\text { marked it. }\end{array}$ & 54 & 27 & 146 & 73 & 12 & 60 & 8 & 40 \\
\hline
\end{tabular}

Table 9. Students and teachers views regarding how students feel about their teacher comments

\begin{tabular}{|c|c|c|c|c|c|c|c|c|}
\hline \multirow{2}{*}{$\begin{array}{l}\text { 9. How do you feel about your teacher } \\
\text { comments? }\end{array}$} & \multicolumn{4}{|c|}{ Students } & \multicolumn{4}{|c|}{ Teachers } \\
\hline & $\mathrm{Y}$ & $\%$ & $\mathrm{~N}$ & $\%$ & $\mathrm{Y}$ & $\%$ & $\mathrm{~N}$ & $\%$ \\
\hline $\begin{array}{l}\text { 43) My teacher's comments are too } \\
\text { negative and discouraging. }\end{array}$ & 20 & 10 & 180 & 90 & 4 & 20 & 16 & 80 \\
\hline $\begin{array}{l}\text { 44) My teacher's comments are too } \\
\text { general. }\end{array}$ & 88 & 44 & 112 & 56 & & & 20 & 100 \\
\hline $\begin{array}{l}\text { 45) I enjoy the teacher's comments on } \\
\text { my composition. }\end{array}$ & 187 & 93.5 & 13 & $\begin{array}{l}6 . \\
5\end{array}$ & 10 & 50 & 10 & 50 \\
\hline $\begin{array}{l}\text { 46) My teacher's comments and } \\
\text { corrections help me to know what to } \\
\text { avoid/improve next time. }\end{array}$ & 160 & 80 & 40 & 20 & 16 & 80 & 4 & 20 \\
\hline $\begin{array}{l}\text { 47) My teacher's comments and } \\
\text { corrections help me to know where my } \\
\text { mistakes are and correct them. }\end{array}$ & 175 & 82.5 & 25 & $\begin{array}{l}12 \\
.5\end{array}$ & 14 & 70 & 6 & \\
\hline $\begin{array}{l}\text { 48) The feedback given makes me want } \\
\text { to try harder to improve in my writing. }\end{array}$ & 164 & 82 & 36 & 18 & 14 & 70 & 6 & 30 \\
\hline $\begin{array}{l}\text { 49) The feedback given makes me feel } \\
\text { good about myself. }\end{array}$ & 154 & 77 & 46 & 23 & 16 & 80 & 4 & 20 \\
\hline $\begin{array}{l}\text { 50) I feel that my writing has improved } \\
\text { because of the feedback given on my } \\
\text { paper. }\end{array}$ & 150 & 75 & 50 & 25 & 16 & 80 & 4 & 20 \\
\hline $\begin{array}{l}\text { 51) Generally, I like the way my } \\
\text { composition is marked. }\end{array}$ & 170 & 85 & 30 & 15 & 16 & 80 & 4 & 20 \\
\hline
\end{tabular}


Table 10.Teachers' difficulties in providing feedback

\begin{tabular}{|l|l|}
\hline Problems & $\begin{array}{l}\text { Number of } \\
\text { mentions }\end{array}$ \\
\hline a.It takes a lot of time and effort to give comment. & $18(90 \%)$ \\
\hline b.There are too many papers to mark. & $19(95 \%)$ \\
\hline c.Students make too many mistakes. & $12(60 \%)$ \\
\hline d. Students don't read teachers' comments, they only look at the mark given. & $6(30 \%)$ \\
\hline e. Students don' understand the feedback. & $2(10 \%)$ \\
\hline
\end{tabular}

Table 11. Difficulties of the students in revising the papers after receiving feedback

\begin{tabular}{|c|c|}
\hline Statements & $\begin{array}{l}\text { Number of } \\
\text { mentions }\end{array}$ \\
\hline a. I don't have any problems in rewriting my paper after getting feedback. & $71(35.5 \%)$ \\
\hline $\begin{array}{l}\text { b. I can't correct all the grammatical and mechanic mistakes that the teacher } \\
\text { points out. }\end{array}$ & $65(32.5 \%)$ \\
\hline c. I can't revise the content and the expressions suggested by the teacher. & $60(30 \%)$ \\
\hline d. I am afraid of making other new mistakes. & $71(35.5 \%)$ \\
\hline e. I don't understand the teacher written feedback. & $51(25.5 \%)$ \\
\hline f. I don't have sufficient time to revise the drafts. & $46(23 \%)$ \\
\hline h. I have too many mistakes to revise. & $40(20 \%)$ \\
\hline i The teacher written feedback is not always helpful. & $40(20 \%)$ \\
\hline $\begin{array}{l}1 \text { I don't know how to rewrite the papers even after receiving the teacher } \\
\text { written feedback. }\end{array}$ & $18(9 \%)$ \\
\hline
\end{tabular}

